\title{
The comparison of health literacy between health science and non-health science members-A cross sectional study of multifaceted public health affair
}

\author{
Felcita Lavina Cuthino ${ }^{a}$, Melita Sheilini ${ }^{\text {a, * }}$, Ramesh Chandrababu ${ }^{\text {b }}$ \\ ${ }^{a}$ Department of Medical Surgical Nursing, Manipal College of Nursing, Manipal Academy of Higher Education, Manipal, Karnataka, 576104, India \\ ${ }^{\mathrm{b}}$ Department of Medical Surgical Nursing, Sri Ramachandra Faculty of Nursing, Sri Ramachandra Institute of Higher Education and Research, Porur, Chennai, 600116, \\ India
}

\section{A R T I C L E I N F O}

\section{Keywords:}

Health literacy

Health promotion

Health barriers

Health behaviour

Health outcomes

\begin{abstract}
A B S T R A C T
Background/Objectives: Health literacy is a global concern and is varied across the general population. It is the means to enhance public access to health information and services. The objective of this study was to compare the health literacy among health science and non-health science members and to identify the barriers to health literacy.

Methods: A cross-sectional study was conducted among the faculty of health sciences and health sciences teaching institutes. A total of 230 samples were included using stratified proportionate sampling. The Health Literacy Questionnaire (HLQ) and the tool on perceived barriers to health literacy were used to collect the data.

Results: The health literacy among health sciences people was better compared to the non-health sciences people $(\mathrm{p}<0.05)$ in all the domains. The Cohen's d effect size showed that the difference was statistically significant (Effect size between $>0.2$ and $<0.8$ ). The top four barriers for health literacy identified were: Home remedies are preferred to medicines for minor ailments, failure to meet doctors due to the job timings, inability to take care of self-due to busy working hours, and priority for the health of family members than one's own health. Conclusion: Health literacy is an important factor that helps every individual to make health-care decisions and enhances one's ability to get the right information. Evaluating the barriers to health literacy gives us the specific areas of concern. The relevant measures must be implemented to improve the knowledge and health literacy, which can lead to better health outcomes.
\end{abstract}

\section{Introduction}

Health literacy is gaining momentum in the public health arena. Health literacy refers to the personal characteristics and social resources needed for individuals and communities to access, understand, appraise and use information and services to make decisions about health. Health literacy includes the capacity to communicate, assert and enact these decisions. ${ }^{1,2}$ Inadequate health literacy has a strong impact on various health outcomes including lower utilization rate of preventive measures and emergency services, higher hospitalization rate and healthcare costs, health behaviour, and health equity. ${ }^{3}$ Lack of health literacy poses a great threat to our nation's economic stability as health care expenditures are on the rise, along with an expanding population. As a result of overpopulation, access to quality health care and reliable health information can be difficult to come by. ${ }^{4}$
Health literacy surveys among different countries is done to assess health literacy and its barriers, but very little is known about health literacy and barriers to health literacy in India. There are no comprehensive studies done on health literacy in India so far; we can assume on the basis of existing health indicators that the level of health literacy in India is less than desirable -not because of poor planning but mostly due to poor awareness, implementation, and barriers which are yet to be explored. ${ }^{5}$

It is necessary to know the health literacy in India to be able to build an enhanced health care system and by means of health education, communication and advocacy, bridge the gap between the health care professionals and the common population. The National Assessment of Adult Literacy survey conducted in USA also revealed the low level of health literacy (proficient health literacy-12\% and intermediate health literacy-53\% with more than one third below basic and basic health

\footnotetext{
* Corresponding author. Department of Medical Surgical Nursing, Manipal College of Nursing, Manipal Academy of Higher Education, Manipal, Karnataka, 576104, India.

E-mail addresses: shyli.mel@manipal.edu (M. Sheilini), ramesh.c@sriramachandra.edu.in (R. Chandrababu).
} 
literacy level). ${ }^{6}$

As per the report of the health literacy published in the e-paper 'The Tribune' In India in 2019; at least nine out of 10 adults suffer from low health literacy. Having high rate of illiteracy and glaring poverty, India is become the hub for many diseases. This is one of the reason for the tragic spread of infection and hike in mortality observed in the current COVID pandemic. Investing on health literacy is like investing on the global health. So it is very critical to empower the communities against the emerging threats and battle against the health crisis by strengthening the weapon of health literacy within each individual.

A cross-sectional study conducted in coastal areas of Karnataka to evaluate the health literacy among patients in tertiary care hospital showed that, among females, $72.9 \%$ participants had low literacy and $27.1 \%$ had higher literacy. The study helped in gaining an insight on the health literacy of the people visiting the tertiary care centre and develop methods to enhance communication between the health professionals and the patients. ${ }^{8}$ Another study which was conducted in India was among patients attending The Oxford Dental College, Hospital and Research Centre, Bangalore in the outpatient department using modified tool designed by Chew and colleagues to assess the health literacy among the out-patients. Around 500 participants were subjected to this study, among which $60.4 \%$ had low health literacy, $29.4 \%$ had average health literacy and $10.2 \%$ had high health literacy. Based on the education level (graduates and post graduates) health literacy was assessed, among 119 graduates, 53.7\% had low health literacy, 29.4\% had average health literacy and $16.8 \%$ had high health literacy. Among 64 postgraduates $57.8 \%$ had low health literacy. ${ }^{9}$

The health professionals need to know the barriers to health literacy to understand the shortcomings in meeting the health literacy. A qualitative study done in India in the regions of West-Bengal to assess the communication challenges in achieving health literacy concluded that the barriers to health literacy among the general population were: Language barrier, Financial barrier, Psychological barrier, Connectivity barrier, Infrastructural barrier, Literacy barrier. ${ }^{10}$

The present study could help in obtaining data on health literacy and thus help in planning strategies to improve health literacy among the public. The objectives of the study were to determine the health literacy, to identify the barriers to health literacy and to compare the health literacy between health science and non-health science members.

\section{Methods}

The cross sectional study was conducted in the teaching institutes among 230 subjects using stratified proportionate sampling. The strata included ten teaching institutes and based on the total number of faculty present in each strata, the sample were selected proportionately to reach the estimated sample size. Within the strata the subjects were taken using purposive sampling. Equal numbers of subjects were taken from health science and non-health science institutes i.e., 115 each.

Ethical clearance was obtained from the Institute of Ethical Committee (IEC 741/2017) and to ensure transparency and enhance visibility; the study was registered with the Clinical Trials Registry India (CTRI/2018/02/011741). The sample were selected based on the sampling criteria and a written informed consent was obtained from the participants. The data was collected by self-administering demographic proforma and Health Literacy Questionnaire and tool to assess barriers to health literacy. Demographic proforma consisted of age, gender, religion, education, profession, work setting, nationality, presence of health care professionals in the family and attending the health education or health literacy sessions, suffering from chronic illness.

Health Literacy Questionnaire (HLQ) is a standardised tool. HLQ is a critical advancement in health literacy measurement. The HLQ consists of 44 questions and can be either self administered or orally administered. These questions were categorized into 9 domains they are: Feeling understood and supported by health care providers, Having sufficient information to manage health, Actively managing my health, Social
Table 1

Frequency and percentage of demographic characteristics $[\mathrm{N}=230(115+$ 115)].

\begin{tabular}{|c|c|c|c|c|}
\hline \multirow[t]{2}{*}{ Sample characteristics } & \multicolumn{2}{|c|}{$\begin{array}{l}\text { Health } \\
\text { science }\end{array}$} & \multicolumn{2}{|c|}{$\begin{array}{l}\text { Non-health } \\
\text { science }\end{array}$} \\
\hline & $\mathrm{f}$ & $\%$ & $\mathrm{~F}$ & $\%$ \\
\hline \multicolumn{5}{|l|}{ Age in years } \\
\hline $20-29$ & 16 & 13.9 & 25 & 21.7 \\
\hline $30-39$ & 54 & 47.0 & 50 & 43.5 \\
\hline $40-49$ & 38 & 33.0 & 29 & 25.2 \\
\hline $50-59$ & 5 & 4.3 & 9 & 7.8 \\
\hline Above 60 & 2 & 1.7 & 2 & 1.7 \\
\hline \multicolumn{5}{|l|}{ Gender } \\
\hline Male & 47 & 40.9 & 63 & 54.8 \\
\hline Female & 68 & 59.1 & 52 & 45.2 \\
\hline \multicolumn{5}{|l|}{ Religion } \\
\hline Hindu & 86 & 74.8 & 94 & 81.7 \\
\hline Muslim & 7 & 6.1 & 6 & 5.2 \\
\hline Christian & 22 & 19.1 & 12 & 10.4 \\
\hline Others & 0 & 0 & 3 & 2.6 \\
\hline \multicolumn{5}{|l|}{ Education } \\
\hline Graduate & 6 & 5.2 & 7 & 6.1 \\
\hline Post-graduate & 84 & 73.0 & 79 & 68.7 \\
\hline $\mathrm{PhD}$ & 25 & 21.7 & 29 & 25.2 \\
\hline \multicolumn{5}{|c|}{$\begin{array}{l}\text { Presence of health care professionals in the } \\
\text { family }\end{array}$} \\
\hline Yes & 77 & 67.0 & 47 & 40.9 \\
\hline No & 38 & 33.0 & 68 & 59.1 \\
\hline \multicolumn{5}{|c|}{$\begin{array}{l}\text { Attending a health education or health literacy } \\
\text { session }\end{array}$} \\
\hline Yes & 85 & 73.9 & 47 & 40.9 \\
\hline No & 30 & 26.1 & 68 & 59.1 \\
\hline \multicolumn{5}{|c|}{ Presence of chronic illness } \\
\hline Yes & 11 & 9.6 & 10 & 8.7 \\
\hline No & 104 & 90.4 & 105 & 91.3 \\
\hline
\end{tabular}

support for health, Appraisal of health information, Ability to actively information engage with healthcare providers, Navigating the healthcare system, Ability to find good health information, Understand the health information well enough to know what to do. It usually takes between 7 and $30 \mathrm{~min}$ to complete. Permission to use the questionnaire for the present study was obtained from the Deakin University.

Tool on perceived barriers to health literacy had 15 items. It was a 4point rating scale (4- strongly agree, 3 - agree, 2- disagree, 1 - strongly disagree). Among the 15 items, two items were negatively stated, for those statements the scoring was reversed. The interpretation was based on mean score and frequency and percentage. Higher the mean more are the barriers. Pretesting was done among five faculty members.

The participants took 10-15 min to answer both the questionnaires. Reliability was established among 20 faculty members. The reliability established by the author was 0.88 for the Health Literacy Questionnaire (HLQ) and the reliability established in Indian setting was found to be 0.95 . The reliability of the tool on perceived barriers to health literacy was 0.88 .

\section{Results}

A total of 230 responses were analysed. Among health science members 54 (47\%) and non-health science members 50 (43.5\%) belonged to the age group of 30-39 years. About 68 (59.1\%) were females among health science members and 63 (54.8\%) were males among non-health science members. Most of the participants belonged to Hindu religion, among which $86(74.8 \%)$ were from health science and $94(81.7 \%)$ from non-health science members. Post graduates were more in number among both health science 84 (73\%) and non-health science members $79(68.7 \%)$. Among the health science members, majority $77(67 \%)$ had health care professionals in their family and 85 (73.9\%) had attended health education sessions. Among both health science and non-health science members, majority 104 (90.4\%) and 105 $(91.3 \%)$ of the participants did not have chronic illness respectively 
Table 2

Comparing means of domains of health literacy among health science and non-health science members $[\mathrm{N}=230(115+115)]$.

\begin{tabular}{|c|c|c|c|c|c|c|c|c|}
\hline \multirow[t]{2}{*}{ Domains of health literacy } & \multicolumn{2}{|c|}{ Health science } & \multicolumn{2}{|c|}{ Non health science } & \multirow[t]{2}{*}{$\mathrm{t}$ value } & \multirow[t]{2}{*}{ df } & \multirow[t]{2}{*}{$\mathrm{p}$ value } & \multirow[t]{2}{*}{ ES } \\
\hline & Mean & SD & Mean & SD & & & & \\
\hline Feeling understood and supported by health care providers & 3.21 & .55 & 2.97 & .61 & 3.09 & 228 & $.002^{*}$ & 0.40 \\
\hline Having sufficient information to manage health & 3.20 & .46 & 2.88 & .44 & 5.27 & 228 & $<.001 *$ & 0.69 \\
\hline Actively managing my health & 3.04 & .52 & 2.89 & .50 & 2.16 & 228 & $.032 *$ & 0.28 \\
\hline Social support for health & 3.26 & .46 & 3.06 & .54 & 2.16 & 228 & $.004^{*}$ & 0.38 \\
\hline Appraisal of health information & 3.18 & .46 & 2.91 & .52 & 4.21 & 228 & $<.001^{*}$ & 0.55 \\
\hline Ability to actively engage information with healthcare providers & 3.93 & .60 & 3.68 & .67 & 2.99 & 228 & $.003^{*}$ & 0.39 \\
\hline Navigating the healthcare system & 3.91 & .59 & 3.53 & .70 & 4.38 & 228 & $<.001 *$ & 0.58 \\
\hline Ability to find good health information & 3.92 & .59 & 3.60 & .64 & 3.93 & 228 & $<.001^{*}$ & 0.51 \\
\hline Understand the health information well enough to know what to do & 4.07 & .53 & 3.65 & .64 & 5.41 & 228 & $<.001 *$ & 0.71 \\
\hline
\end{tabular}

ES: Effect Size.

Table 3

Perceived barriers to health literacy among health science and non- health science members $[\mathrm{N}=230(115+115)]$.

\begin{tabular}{lllll}
\hline $\begin{array}{l}\text { Perceived Barriers to } \\
\text { Health Literacy }\end{array}$ & Mean & $\begin{array}{l}\text { Standard } \\
\text { deviation }\end{array}$ & $\begin{array}{l}\text { Minimum } \\
\text { score }\end{array}$ & $\begin{array}{l}\text { Maximum } \\
\text { score }\end{array}$ \\
\hline Health science & 32.65 & 5.86 & 15 & 60 \\
Non health science & 34.65 & 5.82 & & \\
\hline
\end{tabular}

\section{Table 4a}

Frequency and percentage of perceived barriers to health literacy among health science and non- health science members $[\mathrm{N}=230(115+115)]$.

\begin{tabular}{|c|c|c|c|}
\hline \multirow[t]{2}{*}{ Barriers } & & \multirow{2}{*}{$\begin{array}{l}\text { Health } \\
\text { science } \\
\mathrm{f}(\%)\end{array}$} & \multirow{2}{*}{$\begin{array}{l}\text { Non health } \\
\text { science } \\
\text { f (\%) }\end{array}$} \\
\hline & & & \\
\hline \multirow[t]{4}{*}{$\begin{array}{l}\text { Failure to meet doctors due to the job } \\
\text { timings. }\end{array}$} & $\begin{array}{l}\text { Strongly } \\
\text { disagree }\end{array}$ & $14(12.2)$ & $4(3.4)$ \\
\hline & Disagree & $36(31.3)$ & $28(24.3)$ \\
\hline & Agree & $51(44.3)$ & $61(53.1)$ \\
\hline & $\begin{array}{l}\text { Strongly } \\
\text { agree }\end{array}$ & $14(12.2)$ & $22(19.2)$ \\
\hline \multirow[t]{4}{*}{ Have sufficient information on health } & $\begin{array}{l}\text { Strongly } \\
\text { disagree }\end{array}$ & $2(1.7)$ & $1(0.9)$ \\
\hline & Disagree & $42(36.5)$ & $28(24.3)$ \\
\hline & Agree & $52(45.3)$ & $74(64.4)$ \\
\hline & $\begin{array}{l}\text { Strongly } \\
\text { agree }\end{array}$ & 19 (16.5) & $12(10.4)$ \\
\hline \multirow[t]{4}{*}{$\begin{array}{l}\text { Consuming medications without } \\
\text { medical consultation }\end{array}$} & $\begin{array}{l}\text { Strongly } \\
\text { disagree }\end{array}$ & 20 (17.4) & 31 (26.9) \\
\hline & Disagree & $54(46.9)$ & $55(47.8)$ \\
\hline & Agree & $36(31.3)$ & $24(20.9)$ \\
\hline & $\begin{array}{l}\text { Strongly } \\
\text { agree }\end{array}$ & $5(4.4)$ & $5(4.4)$ \\
\hline \multirow[t]{4}{*}{$\begin{array}{l}\text { Scared to visit the hospital for health } \\
\text { problems }\end{array}$} & $\begin{array}{l}\text { Strongly } \\
\text { disagree }\end{array}$ & 35 (30.4) & 31 (26.9) \\
\hline & Disagree & $54(46.9)$ & $51(44.3)$ \\
\hline & Agree & $22(19.2)$ & $26(22.7)$ \\
\hline & $\begin{array}{l}\text { Strongly } \\
\text { agree }\end{array}$ & $4(3.5)$ & $7(6.1)$ \\
\hline \multirow[t]{4}{*}{$\begin{array}{l}\text { Fear of investigations/diagnostic } \\
\text { procedures }\end{array}$} & $\begin{array}{l}\text { Strongly } \\
\text { disagree }\end{array}$ & $32(27.8)$ & $28(24.3)$ \\
\hline & Disagree & $51(44.3)$ & $48(41.7)$ \\
\hline & Agree & $29(25.3)$ & $31(26.9)$ \\
\hline & $\begin{array}{l}\text { Strongly } \\
\text { agree }\end{array}$ & $3(2.6)$ & $7(6.1)$ \\
\hline \multirow[t]{4}{*}{$\begin{array}{l}\text { Home remedies are preferred to } \\
\text { medicines for minor ailments. }\end{array}$} & $\begin{array}{l}\text { Strongly } \\
\text { disagree }\end{array}$ & $10(8.7)$ & $5(4.4)$ \\
\hline & Disagree & $32(27.8)$ & $10(8.7)$ \\
\hline & Agree & $49(42.6)$ & $66(57.3)$ \\
\hline & $\begin{array}{l}\text { Strongly } \\
\text { agree }\end{array}$ & $23(20)$ & $33(28.6)$ \\
\hline \multirow{4}{*}{$\begin{array}{l}\text { Hesitation to clarify the doubts } \\
\text { regarding health issues with the } \\
\text { physicians. }\end{array}$} & $\begin{array}{l}\text { Strongly } \\
\text { disagree }\end{array}$ & 33 (28.6) & 33 (28.6) \\
\hline & Disagree & $63(54.8)$ & $64(55.8)$ \\
\hline & Agree & $16(13.9)$ & $17(14.7)$ \\
\hline & $\begin{array}{l}\text { Strongly } \\
\text { agree }\end{array}$ & $3(2.7)$ & $1(0.9)$ \\
\hline
\end{tabular}

Table $4 b$

Frequency and percentage of perceived barriers to health literacy among health science and non- health science members $[\mathrm{N}=230(115+115)]$.

\begin{tabular}{|c|c|c|c|}
\hline \multirow[t]{2}{*}{ Barriers } & & \multirow{2}{*}{$\begin{array}{l}\text { Health } \\
\text { science } \\
\mathrm{f}(\%)\end{array}$} & \multirow{2}{*}{$\begin{array}{l}\text { Non health } \\
\text { science } \\
\text { f (\%) }\end{array}$} \\
\hline & & & \\
\hline \multirow{4}{*}{$\begin{array}{l}\text { Difficulty in understanding certain } \\
\text { medical terms used by the health care } \\
\text { professionals }\end{array}$} & $\begin{array}{l}\text { Strongly } \\
\text { disagree }\end{array}$ & $45(39.1)$ & $14(12.1)$ \\
\hline & Disagree & $56(48.6)$ & $41(35.5)$ \\
\hline & Agree & $13(11.4)$ & $52(45.5)$ \\
\hline & $\begin{array}{l}\text { Strongly } \\
\text { agree }\end{array}$ & $1(0.9)$ & $8(6.9)$ \\
\hline \multirow[t]{4}{*}{$\begin{array}{l}\text { Priority for the health of family } \\
\text { members than one's own health }\end{array}$} & $\begin{array}{l}\text { Strongly } \\
\text { disagree }\end{array}$ & $7(6.1)$ & $6(5.2)$ \\
\hline & Disagree & $33(28.7)$ & $27(23.5)$ \\
\hline & Agree & $52(45.2)$ & $65(56.5)$ \\
\hline & $\begin{array}{l}\text { Strongly } \\
\text { agree }\end{array}$ & $23(20)$ & $16(13.9)$ \\
\hline \multirow[t]{4}{*}{$\begin{array}{l}\text { Inability to take care of self-due to busy } \\
\text { working hours }\end{array}$} & $\begin{array}{l}\text { Strongly } \\
\text { disagree }\end{array}$ & $12(10.4)$ & $8(6.9)$ \\
\hline & Disagree & $41(35.7)$ & $38(33.0)$ \\
\hline & Agree & 47 (40.9) & $51(44.4)$ \\
\hline & $\begin{array}{l}\text { Strongly } \\
\text { agree }\end{array}$ & $15(13.0)$ & $18(15.7)$ \\
\hline \multirow[t]{4}{*}{ Unable to make health care decisions } & $\begin{array}{l}\text { Strongly } \\
\text { disagree }\end{array}$ & $27(23.4)$ & $16(13.9)$ \\
\hline & Disagree & $62(53.9)$ & $55(47.9)$ \\
\hline & Agree & $21(18.3)$ & $40(34.8)$ \\
\hline & $\begin{array}{l}\text { Strongly } \\
\text { agree }\end{array}$ & $5(4.4)$ & $4(3.4)$ \\
\hline \multirow[t]{4}{*}{ Having good family support } & $\begin{array}{l}\text { Strongly } \\
\text { disagree }\end{array}$ & $14(12.1)$ & $8(6.9)$ \\
\hline & Disagree & $21(18.3)$ & $6(5.3)$ \\
\hline & Agree & $37(32.3)$ & $59(51.3)$ \\
\hline & $\begin{array}{l}\text { Strongly } \\
\text { agree }\end{array}$ & $43(37.3)$ & $42(36.5)$ \\
\hline \multirow[t]{4}{*}{ Non- Supportive work environment } & $\begin{array}{l}\text { Strongly } \\
\text { disagree }\end{array}$ & $35(30.4)$ & $20(17.4)$ \\
\hline & Disagree & $67(58.3)$ & $76(66.1)$ \\
\hline & Agree & $8(6.9)$ & $17(14.8)$ \\
\hline & $\begin{array}{l}\text { Strongly } \\
\text { agree }\end{array}$ & $5(4.4)$ & $2(1.7)$ \\
\hline \multirow{4}{*}{$\begin{array}{l}\text { Insufficient time is provided by the } \\
\text { health care provider to discuss about } \\
\text { the health problem }\end{array}$} & $\begin{array}{l}\text { Strongly } \\
\text { disagree }\end{array}$ & $27(23.5)$ & $13(11.3)$ \\
\hline & Disagree & $68(59.1)$ & $64(55.7)$ \\
\hline & Agree & $11(9.6)$ & $34(29.6)$ \\
\hline & $\begin{array}{l}\text { Strongly } \\
\text { agree }\end{array}$ & $9(7.8)$ & $4(3.4)$ \\
\hline \multirow[t]{4}{*}{ Lack of patient information services } & $\begin{array}{l}\text { Strongly } \\
\text { disagree }\end{array}$ & $32(27.8)$ & $11(9.6)$ \\
\hline & Disagree & $62(53.9)$ & $58(50.4)$ \\
\hline & Agree & $14(12.2)$ & $41(35.6)$ \\
\hline & $\begin{array}{l}\text { Strongly } \\
\text { agree }\end{array}$ & $7(6.1)$ & $5(4.4)$ \\
\hline
\end{tabular}

(Table 1).

Health literacy scores were analysed by mean and standard deviation. To compare health literacy scores among health science and non- 
health science members independent ' $t$ ' test and Cohen's ' $d$ ' effect size was used. The health literacy scores across all nine domains between heath science and non-health science members were significant at 0.05 level (Table 2).

The standardised difference between means of all domains was estimated using Cohen's d effect size. There was small effect size $(>0.2$ to $<0.5$ ) in the domains of Feeling understood and supported by health care providers, Actively managing my health, Social support for health, Ability to actively engage information with healthcare providers. There was medium effect size $(>0.5$ to $<0.8)$ in the domains of Having sufficient information to manage health, Appraisal of health information, Navigating the healthcare system, Ability to find good health information, Understand the health information well enough to know what to do. This shows that the difference between the health science and nonhealth science members was statistically significant (Table 2).

Barriers to health literacy were analysed using frequency and percentage and mean. The mean of barriers to health literacy was higher among the non-health science members (34.65) when compared to health science members (32.65) (Table 3). The top four barriers for health literacy identified were: Home remedies are preferred to medicines for minor ailments, failure to meet doctors due to the job timings, inability to take care of self-due to busy working hours, priority for the health of family members than one's own health (Tables $4 a$ and $4 b$ ).

\section{Discussion}

The HLQ has measurement veracity at the patient and clinician level. It also indicates the important implications for the depth and quality of care that a patient might receive if clinicians can detect when they perceive a patient's health literacy to be different from the way the patient sees it. ${ }^{11}$ The present study shows that the mean scores of the domains of HLQ i.e., Appraisal of health information (among first 5 scales) and Navigating the healthcare system (among 4 scales) were the least among health science members (3.18 and 3.91 respectively) when compared to the mean scores of other domains.

The mean score in the domain of social support for health (among first 5 scales) and understand the health information well enough to know what to do (among 4 scales) were the highest score among all domains ( 3.26 and 4.07 respectively). This is in support of the existing literatures, where it unveiled similar findings. ${ }^{12,13,14}$ In contrary to the present study findings, a qualitative study revealed that the health professionals had an insufficient understanding of health literacy and of the significances of low health literacy for their native patients. ${ }^{15}$

Difficulties with health literacy among patients and the lack of awareness about the importance of health literacy among physicians are thought to be contributing factors leading to health disparities. ${ }^{16}$ Low health literacy is a barrier to effective communication. Low health literacy in patients may be associated with language and cultural barriers. ${ }^{17}$ The top four barriers for health literacy identified in the present study were: Home remedies are preferred to medicines for minor ailments, failure to meet doctors due to the job timings, inability to take care of self due to busy working hours, priority for the health of family members than one's own health. This is in support of the existing literatures, where the social, systemic and cultural barriers were identified as hindrance in improving health literacy. ${ }^{15,18}$

\section{Conclusion}

This study identified that the health literacy was less among health science members when compared to non-health science members. More barriers were identified among non-health health professionals. Therefore, steps need to be taken to improve health literacy by improving communication between health care personnel and the patients.

\section{Declaration of competing interest}

None to declare.

\section{References}

1 Dodson S, Beauchamp A, Batterham R, Osborne R. Ophelia Toolkit: A Step-by-step Guide for Identifying and Responding to Health Literacy Needs within Local Communities [Internet]. Deakin University; 2017 [cited 2107Aug2]. Available from: www.ophelia. net.au. https://www.ophelia.net.au/bundles/opheliapublic/pdf/DEA1238-Ophel ia-Toolkit-FA-Digital_reduced.pdf.

2 Baker DM. The meaning and the measure of health literacy. J Gen Intern Med. 2016; 21(8):878-883.

3 Tian CY, Xu RH, Mo PK-H, Dong D, Wong EL-Y. Generic health literacy measurements for adults:A scoping review. Int J Environ Res Publ Health. 2020;17 (21):1-18. https://doi.org/10.3390/ijerph17217768.

4 Chapter 13: Health Literacy in India: A Unique Challenge. Health Education Library for People; 2006 [cited 2018Jul28]. Available from: http://www.thebestmedicalcare. com/decoding-medical-gobbleddygook/health-literacy-in-india.html.

5 Kaur R, Rajvanshi H. SWOT analysis of health literacy in India. Int J Health Care Edu Med Info. 2017;4(2):28-31.

6 Cutilli CC, Bennett IM. Understanding the health literacy of America results of the national assessment of adult literacy. Orthop Nurs/Nat Assoc Orthoped Nurses. 2009; 28(1):27-34.

7 Kumar R. Health Literacy a Must to Empower Patients; 2019. Retrieved from htt ps://www.tribuneindia.com/news/archive/comment/health-literacy-a-must-to -empower-patients-752945.

8 Belman M, Kamath A. Evaluation of health literacy status among patients in a tertiary care hospital in coastal Karnataka, India. J Clin Diagn Res. 2013;7(11):2551-2554.

9 Das MM. Achieving Health Literacy in India - A Study of the Communication Challenges in Empowering the Common Man. Centre for Planning and Development of Visva-Bharati University; 2011 [Internet]. 2011 [cited 2018Aug2];1-24. Available from: htt p://www.academia.edu/11348478/Achieving_health_literacy_in_India_-_A_study of the_communication_challenges_in_empowering_the_common_man_Theme -_Rural_health_in_India.

10 Hawkins M, Gill SD, Batterham R, Elsworth GR, Osborne RH. The Health Literacy Questionnaire (HLQ) at the patient-clinician interface: a qualitative study of what patients and clinicians mean by their HLQ scores. BMC Health Serv Res. 2017:1-15.

11 Mullan J, Burns P, Weston KM, McLennan PL, Rich WC. Health literacy amongst health professional university students: a study using the Health Literacy Questionnaire. Educ Sci. 2017;7(2):1-11.

12 Beauchamp A, Buchbinder R, Dodson S, et al. Distribution of health literacy strengths and weaknesses across socio-demographic groups: a cross-sectional survey using the Health Literacy Questionnaire (HLQ). BMC Publ Health. 2015;15(678):1-13.

13 Lambert M, Luke J, Downey B, et al. Health literacy: health professionals' understandings and their perceptions of barriers that Indigenous patients encounter. BMC Health Serv Res. 2014:1-10.

14 Rao AP, Sumit K, Soundharya M, et al. Assessing health literacy among health science students in a coastal town of southern India - a cross-sectional study. Indain $J$ Pub Health Res Dev. 2020;11(6):90-94.

15 D'Cruz AM, Acharya MRS. Health literacy among Indian adults seeking dental care. Dent Res J. 2013;10(1):20-24.

16 Maybank A, Dikson T. Breaking Down Health Literacy Barriers. AOA Health Watch; 2008 [cited 2018Jul21]. Available from: www.cecity.com/aoa/healthwatch/ jun_08/print5.pdf.

17 Schyve PM. Language differences as a barrier to quality and safety in health care: the joint commission perspective. J Gen Intern Med. 2009;22(2):1-2.

18 Ravenell JE, Whitaker EE, Johnson Jr WE. According to him: barriers to healthcare among african-American men. J Natl Med Assoc. 2008;100(10):1153-1160. 